\title{
nature
}

\section{What hopes for GM food?}

The industry based on genetic modification of plants has suffered new setbacks. Europe's public is at the least sceptical, but still potentially accepting, of GM crops, provided progress in technology, regulation and communication is maintained.

thas been a grim year for consumer confidence, not least in genetically modified (GM) foods. The discovery in the United States this week that millions of taco shells need to be recalled owing to contamination by potentially allergenic Aventis corn follows on the heels of the episode in May when the Canadian exporter Advanta Seeds accidentally sent GM oilseed-rape seeds to Sweden and the United Kingdom. Couple that to the fact that the international media-tailored campaigns of crop destruction by Greenpeace and others find ready sympathy with much of the public, and GM proponents might contemplate throwing in the towel. The bizarre but unanimous verdict by a British jury last week that such destruction can be lawful, reportedly influenced by a visible sympathy of the jury with Peter Melchett and his Greenpeace co-defendants, sets the seal on such a pessimistic perspective (see page 438). Is there hope for those who, like Nature, adopt an open-minded attitude to the scientific assessment of this technology but also anticipate many benefits from its judicious application?

Uncertainties about the cause of the Advanta contamination are delaying the outcome of a review by the UK Ministry of Agriculture, Fisheries and Food of the crop-separation distances required to achieve acceptably low levels of cross-pollination. But there is no indication that the tens to hundreds of metres recommended for the government's farm-scale trials reflect an underestimation of crosspollination levels. These trials, the targets of Greenpeace's action, are intended to test the hypothesis that the introduction of maize, sugar beet and oilseed rape, modified for herbicide resistance, will not significantly affect biodiversity. Although it is arguable that they are an excuse for the government to delay the commercial introduction of GM crops, there is no doubt that they could play a leading role in addressing relevant ecological questions. Most positively, they may point to ways in which GM crops could encourage biodiversity.

But for anti-GM fundamentalists such as some of those in Greenpeace, and for many with vested interests in organic farming, such knowledge is irrelevant. Tying their beliefs to misleading sound bites about potential risks, constantly exploiting fears and misunderstandings about DNA in food, and in the absence as yet of clear benefits from the technology, they have successfully captured much public sympathy.

But that sympathy can quickly evaporate, especially when the public recognizes the manipulation of information - by industry or anti-technology campaigners - for what it is, as has happened in consensus conferences. More potential benefits of GM crops can be expected to emerge, and one can reasonably expect that problems revealed by the science will, as with any technology, lead to appropriate regulation. In short, public confidence can grow, given a chance.

In the meantime, far better public presentation of the state of the science and stricter regulatory precautions are required in Europe. In Britain, the centre of so much debate, the transparency of advice, contrary to general belief, is good (see, for example, http://www. environment.detr.gov.uk), as is the willingness of scientists to talk at public meetings. But much of that is ignored in the midst of media heat. The fledgling Agriculture and Environment Biotechnology Commission should try to ensure that, as happened during the BSE crisis, advisory bodies respond rapidly to media debates with informed comment and information.

The thresholds of acceptability of some presence of GM product in organic produce need to be pursued as a priority. It is here that the technical and social issues underlying the inherent conflict between organic farming and other types of agriculture can be resolved with a compromise acceptable to most. This will in turn introduce an additional element of rationality when considering the real and apparent risks posed by GM crops.

And Europe's industry needs to speak rather than, as happens too often, remain silent - and to be less careless than their US and Canadian colleagues in controlling the standards of their products.

\section{Triumph, but self-criticism too}

The release of an alleged spy at the Los Alamos laboratory comes none too soon, but prompts other questions.

$\mathrm{T}$ he plea bargain earlier this month that freed nuclear scientist and alleged Los Alamos spy Wen Ho Lee induced jubilation among US scientific leaders. But last week's new disclosure that Lee made copies of the purloined computer tapes of nuclear data makes the accolades premature.

The US government first learned of the additional tapes during the final negotiations for Lee's plea bargain, in which 58 charges were dropped in favour of a guilty plea to a single count of mishandling secret documents. Lee has reportedly insisted they were destroyed. His attorneys only disclosed the copying of the tapes to surprised prosecutors when the plea bargain had been nearly struck, to ensure compliance with plea-bargain stipulations. But it was only uncovered publicly by Newsweek last week, setting off a new round of questions in the already troubling nuclear-secret débâcle.

The Los Alamos secrets case appears to engender hysteria like a nuclear chain reaction: in Congress first, stimulating federal prosecutors to react wildly, providing inaccurate testimony in the effort to convict Lee. And Lee's inhumane treatment during his nine months of incarceration could also be chalked up to that climate. Lee's release has also triggered harsh assessments of government witnesses.

The history of his treatment makes enthusiasm over Lee's release seem entirely justified. Weapons laboratory scientists have much to be proud of, not only for their science (see page 447), but also for so successfully maintaining a balance of scientific openness side by side with the fulfilment of tasks central to the United States' most sensitive defence interests. Yet it is clear from the Lee case that nuclear secrets weren't handled correctly.

The case shows, not for the first time, how scientists need to be ever more scrupulous in adhering to the rules. That is by far the best defence against misbegotten hysteria. 